\title{
Examples of Individual and National Restitution in the Books of Kings
}

\author{
W Thiel \\ (Ruhr-Universität-Bochum, Germany) \\ (Guest: Dept Old Testament, University of Stellenbosch)
}

\section{ABSTRACT}

Examples of Individual and National Restitution in the Books of Kings

The Books of Kings contain some examples of individual restitution in the prophetic narratives: raising from death, restitution from a disastrous illness and restitution of a social position. The main motive in these narratives is the confidence of people in the saving power of the prophet and of God, who uses the magic abilities of the prophet. In the composition of the Deuteronomistic History the national restitution of Israel in 2 Kings 13-14 appears as a chance for Israel to repent. But it was not used, and so the history of Israel inevitably came to an end.

\section{INTRODUCTION}

I The books of Kings are a part of the Deuteronomistic History. This work was composed to explain the fall of Israel and Judah, the destruction of the temple, the removal of the Davidic dynasty and the deportation of large parts of the people as a doom of God. In the events of the years 722 and $587 \mathrm{~B} \mathrm{C}$, the deuteronomistic redactors recognized the consequences of the wrath of God concerning the guilt of his people. Correspondingly, they shaped their work as a history of the permanent guilt of Israel and Judah opposite to God, as a history of growing disaster. In spite of this general intention the Deuteronomistic History contains several narratives and notes of individual and national restitution. The statements about individual restitution are found in the prophetic traditions, which the redactors adapted. The notes about national restitution are contained in the reports about kings, as well as in the redactional comments to these kings. In my paper I have to confirm myself to some examples of this topic.

Three complexes of prophetic traditions dominate large parts of the books of Kings: the Elijah stories (1 Kgs 17-19; 21; $2 \mathrm{Kgs} 1$ ), the Elisha traditions (2 Kgs $2: 1-8: 15 ; 9: 1-13 ; 13: 14-21$ ), and the Isaiah legends (2 Kgs 18-20). These traditions hold the most examples of individual restitution, whether revivals from death (1 Kgs 17:17-24; 2 Kgs 4:8-37; 13:20- 
21) or the restitution of health ( $2 \mathrm{Kgs} 5 ; 20: 1-11)$ or the restitution of social position ( $2 \mathrm{Kgs} 4: 1-7 ; 8: 1-6$ ). Most of these texts come from the Elisha tradition. 1 Kings 17:17-24 is not an independent and original Elijah story, but a parallel tradition to 2 Kings 4:8-37. Both texts go back to a common tradition which is preserved in its older form in 2 Kings $4 * 1$. Therefore, the revival of the deceased boy was probably at first time told about Elisha and later assigned to Elijah (cf the title "man of God" which is unfamiliar to Elijah, but usual to Elisha).

\section{KINGS 4:8-37}

As an example of a revival from death I have chosen 2 Kings 4:8-37. As a parallel tradition I shall consult 1 Kings 17:17-24 in order to compare. The text 2 Kings 4:8-37 is unusual long, and is not a unit. Probably it was expanded by the verses $13-15.29-30 \mathrm{a} .31 .32 \mathrm{~b} .35^{2}$. They mostly deal with Gehazi, the servant of Elisha. Maybe, they go back to a controversial discussion after the death of Elisha about the position of Gehazi in the groups of the prophets ${ }^{3}$.

The original text reported, that a well-to-do woman from Shunem honours Elisha by placing a luxurious furnished chamber to his disposal. As a reward Elisha promises her the birth of a son. The son is born exactly to the fixed point of time. But after several years the son dies. Immediately his mother rides hastily to Mount Carmel where Elisha is staying. Elisha follows her, raises the boy and restitutes the family.

The circumstances of the revival are important. They are unique and occur only here in the whole Old Testament. The revival happens in the chamber of Elisha in the house of the Shunammite woman behind closed doors. It doesn't suffer any witness. The action occurs in strange way: Elisha lays himself upon the dead boy and puts his mouth upon his mouth, his eyes upon his eyes and his hands upon his hands. Then he performs an act of concentration $(r h g)^{4}$. Comparable actions are attested in babylonian exorcism texts 5 and much later in the miracle stories of the type of sunanacrwsis ${ }^{6}$. According to the best parallel from the younger sources 7 the wonder healer passes his miraculous powers on the hopeless ill by contacting the skin. Therefore, the revival of the dead boy happens obviously in a magical way.

But the magical character of the action, in which the miraculous powers of the wonder healer are decisive, is broken in this story. Before Elisha begins with the revival action, he prays to God (v 33b). This sentence is not allowed to detach from the original context as it is 
sometimes proposed ${ }^{8}$. It is indeed a short sentence. But it shows clearly, that the event of revival fully depends on God. The miraculous powers of Elisha don't work autonomously, but they are tied to God's power. He is the initiator of the revival and the restitution of the family.

The parallel in 1 Kings $17 *$ increases clearly the share of God in the revival. The narrator says not only, that Elijah calls to God, but he also mentions the wording of the prayer and emphasizes, that God is listening (v 21). The course of events of 2 Kings 4:34 is not repeated exactly; the verb rhg is avoided. The magical character of the action is reduced; the initiative of God is strongly emphasized. It's the same with the whole context. Here the death of the boy is already traced back to God, in the reproach of the widow to Elijah in verse 18 and in the lamenting question of Elijah to God in verse 20. Prepared by these sentences the revival of the boy can't be nothing else but the work of God. In this connection we also find a possible motivation for the boy's death. The mother accuses Elijah of having directed the attention of God by his presence in her house to her guilt, so that God had killed her son (v 18). In his complaint Elijah doesn't repeat this accusation. It serves as an appeal to Elijah to act. In 2 Kings 4* such a motivation for the death of the son is lacking at all. But here is found a reproach of the woman to the man of God too ( $v$ 28). But it is not as sharp and becoming distance as in 1 Kings 17:189. More important is the woman's confidence in the miraculous and helping power of Elisha, that determines her whole behaviour ${ }^{10}$.

\section{KINGS 5}

As an example for a restitution from a disastrous illness I offer 2 Kings 5, the story of the healing of Naaman the Aramaean. The unity of this extensive text is assessed controversially. Several different models of development are proposed ${ }^{11}$. I prefer a relatively simple solution ${ }^{12}$ : The text is mostly uniform, but it was expanded by the section verse $20-27$ and the verses preparing it: verses $5 b .15 b-17 a a^{*} .19 b^{*}$. They are the parts of the text, which report on the intention of Naaman to bring a gift for Elisha, on the deception of Naaman by Gehazi and on the punishment of Gehazi. Like chapter 4 this expansion deals with the role of Gehazi and is possibly arisen from some discussions about the function of Gehazi in the groups of prophets.

Without this secondary verses the text is a artificially composed, well-rounded unit the single parts of it are tied by some cross-references ${ }^{13}$. As regards content the text is remarkable, because the restitution concerns 
a foreigner, a high-ranking Aramaean officer. "By him Yahweh had given victory to Aram", the narrator remarks on the beginning ( $v 1)$. By this sentence he gives the following story a theological perspective ${ }^{14}$ : The healing of this for his country very important man, now suffering from a severe illness of skin (not leprosy), will only happen by Yahweh, the God of Israel, who obviously is at work over the borders of his country. To this in the beginning ( $v 3$ ) the way of the healing is envisaged also: It shall happen by the prophet who is in Samaria. So it occurs after a retarding scene (vv 5-7) which explains that the king of Israel doesn't possess the necessary healing power.

The right person is Elisha, the prophet in Samaria. To him Naaman is going with his entourage. But he is not allowed to meet Elisha. He only gets the instruction to wash himself seven times in the Jordan. After some outrageous reluctance Naaman fulfils the order and becomes clean in fact. The number seven shows the similarity to a magical action at least. But the context separates this healing from magical and religious actions as such Naaman has expected (v 11). The text generally shows more theological reflexion than most of the other Elisha traditions. The magical component in the activity of Elisha is once more reduced as usual. Especially by the beginning and the end of the story (vv 1.15a.17*-19) is clearly said, that Elisha, the man of God, is only the mediator, the God of Israel is giving healing and restitution by him.

With the words "his flesh became again like the flesh of a young boy" the narrator concludes the description of the healing. He notices by this sentence the restitution of the former health and strength. With the following confession of the Aramaean to the power of the God of Israel reaching across the borders $(15 \mathrm{a} .17 *-19)$ the narrator built a bridge to the very beginning of the story ( $v 1)$.

In this tradition the precondition for the restitution of Naaman consists in the fact, that he believes the report of the captured Israelite girl (v 2-3) and goes to Samaria. The aim of the action is not the restitution only, but the recognition at all ( $v 8)$. By recognizing the healing power of the prophet Elisha Naaman recognizes and confesses the Godness of Yahweh, the God of Israel, which is going beyond the borders.

\section{4 2 KINGS 8:1-6}

2 Kings 8:1-6 looks like a good example for the restitution of a social position. The text is connected with chapter 4:8-37. The central figure of the story is the Shunammite woman whose son Elisha had awaked. The 
wording of the story contains some cross-references to chapter $4^{*}$. But it obviously presupposes, that the woman has become a widow in the course of the years although the word "widow" is not used in the story. Besides this the text shows still another linking to the content of chapter $4^{*}$ and to the expansions of chapter 5: Gehazi, the servant of Elisha, plays an important role in this tradition. But in this story he belongs to the original form. The text is to assess as a unit ${ }^{15}$. But it mentions the names of persons from other Elisha traditions and presupposes its content. Therefore it proves to be a younger text within the Elisha traditions.

According to an instruction of Elisha the woman has left the country together with her family because of an imminent famine and has lived seven years in the land of the Philistines. When she returned she found her property expropriated. The occurrence is not described exactly. But the opinion is probable, that her property as a part of the village estate, which was without owner, was transmitted to the crown property. She was appealing to the king, while Gehazi was telling the king how Elisha had revived her dead son. Thereupon the king gives her back her property and refunds her the harvest of the last years.

In this connection the narrator uses the verb, which is probably the terminus for "restitution": שוב (hi) also has the meanings "to give back, to bring back, to restore, to restitute". In this text it means "to give back, to return" ( $(\mathrm{k}$ ). But according to the integrative thinking of Israel and the Ancient Near East the nuance of restitution certainly is contained in the sentence.

As reasons of the restitution are presupposed in this story the widow's unconditional obedience of Elisha's order - and - still more important - the authority of Elisha at the king's court, an authority that works through the tradition about Elisha yet. Obviously the narrator presupposes that Elisha has died before the return of the Shunammite woman. But he is present in his tradition. The agent of the Elisha tradition is Gehazi. Witnessed by Gehazi's telling a reflection of the authority of Elisha is falling on the woman. While the king restitutes her property conditions he honours the deceased man of God.

\section{KINGS 4:1-7}

With some cautions it is possible to understand 2 Kings 4:1-7 as a story of restitution too. It's true, the widow of a prophetic pupil has not yet lost her both sons as debt slaves to her creditor. But this fate will immediately happen, if some unusual doesn't appear. As a poor widow she isn't able to 
pay back the debts. By the miraculous multiplication of the oil Elisha provides her the resources not only to pay the debts, but as the basic conditions of life for the next time too. Consequently the status of the family is restored in the former way, but more than that: The heavy debts and the obligations connected with them are paid off, and the family has supplies of existence at its disposal.

Elisha is challenged to help by the confidence of the widow who cries to him ( $v 1)$. It is important also, that she is the widow of a member of a prophetic group. As a motive of the widow, to move Elisha to help her, the narrator remarks, that her husband "feared Yahweh" (v 1)17. This single mentioning of Yahweh, the God of Israel, in the beginning of the story throws a theological highlight on the action of Elisha (cf 5:1). His miraculous powers are not autonomously at work, but they are at God's disposal. It is Yahweh who brings about the restitution.

\section{KINGS 2:19-23}

II In the Elisha tradition restitution is also reported of a local community. According to 2 Kings 2:19-23 the men of Jericho inform Elisha, that the situation of the city is good, but the water is bad, because it gives rise for miscarriages ${ }^{18}$. This is a disaster for the community. The inhabitants of the oasis of Jericho ${ }^{19}$ are dependent on the water of the spring, both as drinking water and as means for the irrigating of the fields (therefore v 19 says: "the land gives rise to miscarriages"). As the water both by drinking and by eating of the harvested fruits causes miscarriages, then the existence of the community is dangered extremely. It can only be a question of time, until the settlement is deserted.

The description of the situation (v 19) implicitly contains an appeal on Elisha to help the community and to make possible its surviving. Elisha follows this hidden plea and heals the spring. He pours salt into the spring at the place of the outflow of the water. This is certainly not a natural, but a magical action. The use of a new dish shows this especially. But again the magical character is neutralized by a reference to God. It is a divine saying that Elisha announces ( $\mathrm{v} 21 \mathrm{~b}$ ).

Such divine sayings ${ }^{20}$ appear in other texts of the Elijah and the Elisha tradition: 1 Kings $17: 14 \mathrm{a}^{21}$; 2 Kings $3: 16.17 \mathrm{a} ; 4: 43 * ; 7: 1$ (16b). They begin regularly with the messenger formula. Their contents are similar. They deal with elementary conditions of life, hunger and thirst, food and water. Without exceptions they promise the appeasement of this basic conditions of life. Several sayings may have been exist separately 
once. Sometimes they apparently have given the impetus to the development of a tradition.

This is hardly applicable to this text ${ }^{22}$. The divine saying is by several semantic elements so clearly linked to the context, that it is not probable that it formerly existed separately. It is to assume that it always was handed down in connection with this story. The opinion, that it was originally a word of Elisha, which by insertion of the messenger formula was reshaped to a word of $\mathrm{Yahweh}^{23}$, is not probable. The light discrepancy to verse $22 \mathrm{~b}$ ("according to the word of Elisha") is not sufficient for this decision. The analogy of the other divine sayings, which all contain the messenger formula, witnesses its originality24.

By the divine saying is clearly explained: The inhabitants of Jericho owe the restitution of their basis of life to God, who has appointed Elisha and his magical abilities to this purpose. Death and miscarriages never will be caused by the water of the spring. The survival of the community is secured. The presupposition for this restitution of the normal situation is the confidence of the inhabitants in the power of Elisha and his readiness to help.

III The story telling the healing of the water of Jericho leads us to the theme of the national restitution. Texts about kings take the place of the prophetic narratives. The point of view moves from the separate tradition to the redactional composition.

The Deuteronomistic History is a work describing the gradual decline of Israel and Judah. Regarding this intention it is astonishing to read in this work about national restitution. It is a special surprise that these remarks just occur relating to the northern kingdom of Israel despite the negative judgement which the redactors regularly express about its kings and its population. But the Deuteronomists were theologians and historians. From their sources they have selected what was appropriate to their theological intention. But they have not brought about historical misrepresentation. Their sources gave them the impression of a course of events which not at all straightly led to the ruin, but showed a change of rise and decline till both states finally lost their political existence. The deuteronomistic redactors presupposed this goal of the course of history. But they took care not to smoothen the road to this goal in a way that it seemed to be a continuous decline. 
The most important report about a national restitution is found in the short section on the 41 years reign of Jeroboam II of Israel in 2 Kings 14:23-29. In verse $25 \mathrm{a}$ is reported: "He it was who restored the borders of Israel from Lebo-Hamath to the Sea of Araba". Here the verb השיב is used in a unique way for the restitution of the integrity of the territory. In the textual difficult verse 28 Jeroboam is ascribed the recovery of Damascus and Hamath too. In the context the terminus yet appears for the recovery of the city of Elath, at first by Judah (14:22/2 Chron 26:2), then by Edom ( $2 \mathrm{Kgs}$ $16: 16)^{25}$ as well as for the recovery of Israelite cities, which were captured by the Aramaeans in the time of Jehoahaz of Israel, but now were resti-

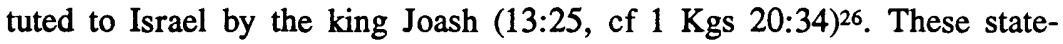
ments about recoveries strikingly appear in a quite limited context, specially in the chapter 13 and 14. Their climax apparently is the verse 14:25a (together with $v 28$ ).

Most of the scholars agree in assessing the verse 14:25a as a historically reliable note taken by the deuteronomistic redactors from the "Book of Chronicles of the Kings of Israel" ${ }^{27}$. The long reign of Jeroboam II inappropriate short treated by the redactors was a last climax in the history of Israel. This is confirmed by the Book of Amos. The prosperity of Israel was possible, because the Aramaean state of Damascus was heavily weakened by the Assyrians, but the Assyrians themselves had to repel the kingdom of Urartu. This temporary vacuum of power made it possible for Jeroboam to restore the old territorial property of Israel between the realm of the modern Bikca plain to the Dead Sea. But it is not certain how to determine exactly the borders of Israel in the north and in the south. For the north the decision depends on the localization of Lebo-Hamath ${ }^{28}$. In the south it is still in dispute regarding Amos 6:14 ("from Lebo-Hamath to the brook of Araba") where the border is to fix ${ }^{29}$. But in this archival date certainly Jeroboam is attributed the restitution of the territory of Israel in the borders of the Davidic and Solomonic kingdom (1 Kgs 8:65), but without Judah. It was an enormous success for Israel that almost had lost its independence by Hazael of Damascus (2 Kgs 13:7).

A more far-reaching statement appears in verse 28 . The sentence is a part of the concluding deuteronomistic framework concerning Jeroboam. Its origin is uncertain. Here is reported, that Jeroboam "restored Damascus and Hamath to Judah in Israel". This note provides unsolved problems. All the solutions which were proposed are not convincing ${ }^{30}$. The understanding corresponds best the wording, that Jeroboam was able to incorporate 
the Aramaean states of Damascus and Hamath into the territory of Israel again (השיב). But this idea is nearly certain excluded. Hamath never belonged to the territory of Israel in the times of David and Solomon. The same holds good for Damascus which was administered as a province and recovered its independence after the accession of Solomon $(1 \mathrm{Kgs}$ 11:2325). The idea, that both states fell in tributary dependence of Israel during the reign of Jeroboam, doesn't accord with the meaning of the verb השיב. Quite uncertain is the meaning of the phrase "to Judah in Israel" (ליאראל ליחודה). In respect to this we can recognize that the statement doesn't include a problem of the tradition only, but a textual problem too. Therefore verse 28 cannot contribute something to the topic.

More important is the theological problem linked with the content of 2 Kings 14:23-29. The deuteronomistic redactors have condemned Jeroboam like all kings of the northern kingdom of Israel, because he "did evil in the sight of Yahweh, not turning from all the sins of Jeroboam the son of Nebat" ( $v$ 24)32. Immediately behind this they file the archival note reporting the unique restitution of Israel by Jeroboam (25a). By doing that they constructed a contrast consciously for several reasons. First of all the statement was particularly important in their opinion, because it reported the fulfilment of an announcement of the prophet Jonah from Gath-hepher. Because the Deuteronomists described the history of Israel as moved by the word of God and announced by the prophets, they couldn't pass over the fulfilment of this announcement of salvation by the prophet Jonah. Jeroboam himself didn't contribute to this success. The restitution of Israel was based on the grace of God alone. The redactors refer to this fact by their theological comment in verses 26-27. Especially verse 27 stresses that God didn't like to realize his threat to blot out the name of Israel (Dtn $9: 14 ; 29: 19)$. Therefore he appointed Jeroboam as a saviour of Israel. This comment recalls the deuteronomistic phraseology in the Book of Judges (cf eg Jdg 6:37) and the likewise deuteronomistic sentence in 2 Kings 13:5.

The Deuteronomists have covered their work with a net of theological comments in order to interpret the described course of events. The history of the northern kingdom Israel is put in an arch of tension reaching from the announcement of the destruction and deportation of Israel attributed to the prophet Ahiah of Shiloh (1 Kgs 14:15-16) to its fulfilment in 2 Kings 17:17-23, the deuteronomistic sermon relating to the end of the northern kingdom. In this course of history the chapters 2 Kings 13-14 bear a special character, because they represent a retarding episode before the fall of Israel. After the extremely bad assessed dynasty of Omri $(1 \mathrm{Kgs}$ $16: 25-26.31-33 ; 22: 53-54)^{33}$ the reign of Jehu begins under promising 
conditions. Designated by a prophetic pupil of Elisha, Jehu seizes the government and destroys the temple of Baal in Samaria. Despite his favourable beginnings Jehu is condemned by the deuteronomistic redactors finally ( $2 \mathrm{Kgs} \mathrm{10:31).} \mathrm{In} \mathrm{immediate} \mathrm{connection} \mathrm{the} \mathrm{redactors} \mathrm{report} \mathrm{about}$ the beginning of the Aramaean threat ( $v$ 32). In this way they interpret the struggles with the Aramaeans as a measure of doom of God against the disobedience of Israel and its king (13:2-3). The distress by the Aramaeans reached its zenith in the reign of Jehoahaz.

But then a decisive change occurs. Jehoahaz turns to God (cf 1 Sam 13:2; $1 \mathrm{Kgs} 13: 6$, as well as 21:27-29), and God has mercy with the misery of Israel (2 Kgs 13:4, cf 14:26). He awakes a saviour for Israel. We don't know whether the Deuteronomists had a tradition about a ritual request $^{34}$ of the king Jehoahaz at their disposal or they had invented this information by themselves. Just as little we do know who is meant with this saviour who removed the hegemony of Damascus ${ }^{35}$.

The next step to the restitution of Israel occurs during the reign of Joash who could recover the cities formerly conquered by the Aramaeans, above all in the east of the Jordan (13:25). The redactors describe this as a sheer act of God's mercy without a previous turning of the king to God. It is possible, that the visit of the king Joash to the seriously ill prophet Elisha and the symbolic action of the prophet (13:14-19) take the part of the turning to God ${ }^{36}$. But God's mercy is limited to a determined time. His reprieving for Israel operates "until now" only (v 23) ${ }^{37}$. In this way the Deuteronomists indicate that the restitution of Israel here reported is an episode only.

In the horizon of this limitation the complete restitution of the territory of Israel by Jeroboam II (14:25) is to understand too. About this king nothing is reported that is tantamount to a turning to God. Only because God doesn't like to destroy Israel in this moment, he empowers the king to save Israel ( $v 27$ ).

But then the history of Israel rushes towards its end. With short strokes, seldom interrupted by their own interpretations, the redactors outline the way of Israel in the destruction $(15: 8-31 ; 17: 1-6)$, and then they give the reasons for the decline in a large sermon (17:7-23). The restitution of Israel only was a temporary one. Possibly the Deuteronomists looked at this period as a chance for Israel to repent ${ }^{38}$. But it was not used, and so the destruction of Israel was inevitable.

These observations should be confirmed and completed by an examination of the deuteronomistic composition of the history of Judah. Now it is not possible any more. But I can remark at least, that in the deutero- 
nomistic composition Judah also has experienced a period of religious renewal and the attempt of a territorial restitution of the old extent of Israel shortly before the end ( $2 \mathrm{Kgs}$. 23). But the merits of Josiah couldn't reverse the judgement of God. The Deuteronomists justify this fact with the weight of the sins of Manasseh (23:25-27), a something forced reason.

\section{CONCLUSION}

For the redactors of the Deuteronomistic History the topic of the national restitution covers a little part of their work and of their theological programme. It witnesses the mercy and the readiness of God to forget and to forgive. The presupposition for it however was the repentance of Israel and its representatives. In this way the Deuteronomists formulate a message to the audience of their own time, the time of the exile: interpretation of the present situation as consequence of the judgement of God and encouragement towards the repentance and a new obedience.

\section{NOTES:}

1 Cf H-J Stipp, Elischa - Propheten - Gottesmänner (ATSAT 24), St Ottilien 1987, 453-457.

2 Cf A Schmitt, Die Totenerweckung in 2 Kön 4,8-37, BZ NF 19 (1975), 1-25 (1-8); H-J Stipp, op cit, 297f.

3 Cf P Mommer, Der Diener des Propheten. Die Rolle Gehasis in der ElisaÜberlieferung, Gottes Recht als Lebensraum (FS für H J Boecker), NeukirchenVluyn 1993, 101-115. The complete removal of Gehazi from the original text of 2 Kings 4:8-37 is not convincing however. By this way the starting-point for the later development of the text is abandoned.

4 Cf H-C Schmitt, Elisa, Gütersloh 1972, 185 n. 1; W Thiel, Sprachliche und thematische Gemeinsamkeiten nordisraelitischer Propheten-Überlieferungen, Die alttestamentliche Botschaft als Wegweisung (FS für H Reinelt), Stuttgart 1990, 359-376 (364f).

5 Cf S Daiches, Zu II. Kön. IV,34, OLZ 11 (1908), 492f, and now B Becking, Een magisch ritueel in Jahwistisch perspektief: 2 Kon. 4:31-38 (Utrechtse theologische reeks 17), Utrecht 1992.

6 Cf L Bieler, Totenerweckungen durch SUNANACRWSIS, ARW 32 (1935), 228-245; O Weinreich, Zum Wundertypus der SUNANACRWSIS, ibid, 246264.

7 O Weinreich, $A R W 32$ (1935), 248.

8 By H-C Schmitt, op cit, 1972, 93, and E Würthwein, Die Bücher der Könige. 1. Kön. 17 - 2. Kön. 25 (ATD 11,2), Göttingen 1984, 290, 294.

9 Cf I Lande, Formelhafte Wendungen der Alltagssprache im Alten Testament, Leiden 1949, 99 ("Formel der ablehnenden Abgrenzung gegen Andere").

10 The editors of the text have stressed this element by the insertion of verse 30a. 
11 The uniformity of the text is held by H GreBmann, Die älteste Geschichtsschreibung und Prophetie Israels (von Samuel bis Amos und Hosea) (SAT II,1), Göttingen 19212, 296-298; H Gunkel, Geschichten von Elisa (Meisterwerke hebräischer Erzählungskunst I), Berlin (1922), 31-45; R L Cohn, Form and Perspective in 2 Kings V, VT 33 (1983), 171-184; M Cogan/H Tadmor, II Kings (AncB 11), s.1. 1988, 66-68; K A D Smelik, Das Kapitel 2. Könige 5 als literarische Einheit, DBAT 25 (1988), 29-47; R D Moore, God Saves. Lessons from the Elisha Stories (JSOT Suppl 95), Sheffield 1990, 71-84.

Other scholars reckon with a development of the text by several editorial measures: H.-C Schmitt, op cit, 1972, 78-80; E Würthwein, op cit, 1984, 296303; G Hentschel, 2 Könige (NEB.AT 11), Würzburg 1985, 22-24; N C Baumgart, Gott, Prophet und Israel. Eine synchrone und diachrone Auslegung der Naamanerzählung und ihrer Gehasiepisode - 2 Kön 5 (EThSt 69), Leipzig 1994, 209-271.

12 Cf W Thiel, Das "Land" in den Elia- und Elisa-Überlieferungen, Landgabe (FS für J Heller), Praha 1995, 64-75 (72f); W Thiel, Die Erkenntnisaussage in den Elia- und Elisa-Überliefeungen, Von Gott reden (FS für S Wagner), Neukirchen-Vluyn 1995, 255-269 (264). Similarly already J Gray, I \& II Kings (OTL), London $1977^{3}, 502-510$.

13 Cf especially R L Cohn, VT 33 (1983), 171-184.

14 There are no striking reasons to assess this sentence as a later insertion with $\mathrm{H}$.C. Schmitt, op cit, 79; E Würthwein, op cit, 296, 299; N C Baumgart, op cit, $266 f$.

15 Against E Würthwein, op cit, 317f, who separates an old anecdote (1 $\left.\mathrm{aa}^{1} \cdot \mathrm{a}^{3} \cdot \mathrm{b} \cdot 2 \mathrm{aa} \cdot \mathrm{b} \cdot 3.6 \mathrm{a} \cdot \mathrm{ba}\right)$ from several secondary insertions (1 $\left.\mathrm{aa}^{2} \cdot 2 \mathrm{a} B .4 \mathrm{f} .6 \mathrm{bB}\right)$. In this way the content of the original text is too strongly narrowed.

16 Cf W L Holladay, The Root Sûbh in the Old Testament, Leiden 1958, especially $93 \mathrm{f}$.

17 The sentence cannot be assessed as a later insertion of a theological editing with H-C Schmitt, op cit, 99; E Würthwein, op cit, 287f. Against this H-J Stipp, op cit, 277 n. 10.

18 To this meaning of bכ cf HALAT, 1382.

19 The name of the village is lacking in the text. It is only named in the context (vv 15.18). Obviously it is omitted on the occasion of the redactional putting together with the preceding tradition. It is neither necessary nor convincing to ascertain verse $18 \mathrm{aB}$ as the original introduction of the text (so E Würthwein, $a$ $w, 277$, following several predecessors).

20 Cf W Reiser, Eschatologische Gottessprüche in den Elisa-Legenden, ThZ 9 (1953), 321-338; W Thiel, Character and Function of Divine Sayings in the Elijah- and Elisha-Traditions, forthcoming in JSOT.S.

21 This one instance from the Elijah tradition was probably an original part of the Elisha tradition like the other texts. 1 Kings 17:8-16 has developed essentially by a combination of the tradition of 2 Kings $4: 1-7$ with the divine saying now contained in 1 Kings 17:14a.

22 Against W Reiser, $\operatorname{ThZ} 9$ (1953), 328.

23 So E Würthwein, op cit, 277, previously already H-C Schmitt, op cit, 106.

24 It is also not possible to assign all instances of the messenger formula to later editings as H-C Schmitt and E Würthwein do in a different way and with 
different results. For reference and discussion of $\mathrm{W}$ Thiel, Jahwe und Prophet in der Elisa-Tradition, Alttestamentlicher Glaube und Biblische Theologie (FS für H D Preuß), Stuttgart/Berlin/Köln 1992, 93-103.

25 The original text is "Edom" rather than "Aram".

26 It becomes more and more probable that the events described in 1 Kings 20 belong to the time of the dynasty of Jehu and specially to the reign of Joash. Cf W Thiel, Erwägungen zur aramäisch-israelitischen Geschichte im 9. Jahrhundert v Chr, Nachdenken aber Israel, (Bibel und Theologie), FS für K-D Schunck (BEAT 37), Frankfurt am Main 1994, 117-131 (especially 122-127 and the literature mentioned in $\mathrm{n} .46$ ).

27 As two examples for many: J A Montgomery, Archival Data in the Book of Kings, JBL 53 (1934), 46-52 (50); E Würthwein, op cit, 374.

28 It is discussed, whether it is meant a landscape between Lebanon and antiLebanon or a town (modern Lebweh in the upper valley of Orontes). A decision is not possible yet. Cf T F Wei, Hamath, Entrance of, AncB Dictionary III (1992), 36f.

29 It is considered the northern end of the Dead Sea (Wadi Kefren), the valley of the Arnon or the Sered (that would presuppose a subjugation of Moab).

30 M Haran imagines Damascus and Hamath as tributary vassal states of Israel: The Rise and Decline of the Empire of Jeroboam ben Joash, VT 17 (1967), 266297 (278-284). H Tadmor however assumes, that only Damascus, but not Hamath, was subjugated by Jeroboam: Azriyau of Yaudi, ScrHie 8 (1961), 232271 (239-241), followed by J Gray, op cit, 588, and W T Pitard, Ancient Damascus, Winona Lake, Indiana 1987, 176f, 179, 189. E Lipinski thinks, that Damascus lost only the East of Jordan and Hamath the Bikca plain to Israel: Jéroboam II et la Syrie, Storia e tradizioni di Israele. Scritti in onore di J A Soggin, Brescia 1991, 171-176 (171f). J A Montgomery and H S Gehman only reckon with the recovery of the bazars in Damascus (1 Kgs 20:34): J A Montgomery/H S Gehman, A Critical and Exegetical Commentary on The Book of Kings (ICC), Edinburgh 1951, 444.

31 Cf the proposals for the understanding of the text by $S$ Yeivin, "To Judah in Israel" (2 Kings 14:28), Z Shazar Volume. ErIs 10 (1971), 150f (hebr), and I W Provan, 1 and 2 Kings (New International Biblical Commentary: Old Testament Series), Massachusetts 1995, 240. Often the text is corrected according to a proposal by C F Burney, Notes on the Hebrew Text of Kings, Oxford 1903, 230f. A new conjecture is presented by E Lipinski, Scritti in onore di J A Soggin, 171. All these corrections are without basis in the tradition of the text.

A special way of interpretation consists in referring the name "Judah" to a supposed state "Yaudi" (= Sam'al) in northern Syria. This opinion is shared by C H Gordon, Geschichtliche Grundlagen des Alten Testaments, Einsiedeln/ Zürich/Köln 1956, 219; O Eißfeldt, "Juda" in 2. Könige 14,28 und "Judäa" in Apostelgeschichte 2,9 (1963), Kleine Schriften IV, Tübingen 1968, 99-120; "Juda" und Judäa" als Bezeichnung nordsyrischer Bereiche (1964), ibid, 121131; E Würthwein, op cit, 374f. But this opinion is extremely doubtful. The supposed translation ("he restored ... from Yaudi to Israel”) doesn't correspond to the use of the particles.

32 This condemnation is not even a little reduced as it is with regard to Jehoram (2 Kgs 2:3b), Jehu (10:30f) and Hoshea (17:2). 
33 A limited exception is the judgement of Jehoram (2 Kgs 3:2f), which is not quite negative.

34 חלה פנים חלת (halah), cf K Seybold, חלה (ThWT II, Stuttgart et al. 1977, 960971 (969-971).

35 According to the contemporary history at first the Assyrian king Adadnirari III is considered. An anticipation of Jeroboam II (14:27) is less probable. Cf J Briend, Jéroboam II, sauveur d'Israël, Mélanges bibliques et orientaux en l'honneur de M H Cazelles (AOAT 212), Kevelaer/Neukirchen-Vluyn 1981, 4149, who refers the expression to Jeroboam.

36 On condition that the text was available to the deuteronomistic authors of 13:2225 . This is very probable, but is contradicted by E Würthwein, op cit, 363 .

37 The words are lacking in some important manuscripts of the Septuaginta. They are hardly a later gloss however (against J A Montgomery/H S Gehman, op cit, 436; J Gray, op cit, 601). The translators have tried to smoothen the text, because the later location of the author of the remark was too obvious.

38 Cf M Rehm, Das zweite Buch der Könige, Würzburg 1982, 144; P R House, I, 2 Kings (The New American Commentary 8), s.1. 1995, 327. 